\title{
NARRAÇÃO E MEMÓRIA: A HERANÇA DE EVANGELINA EM AZUL-CORVO
}

\section{[Narration and Memory: The Heritage of Evangelina in Azul-Corvo]}

\author{
Thayná Cavalcante Marques ${ }^{1}$ \\ Larissa Warzocha Fernandes Cruvinel ${ }^{2}$
}

Resumo: Este estudo tem o intuito de compreender o narrador no romance Azul-Corvo (2010). Assim, é necessário entender como essa narradora que é Evangelina, se porta tendo diante de si todo um trabalho acerca da angariação e organização de memórias, essas, por vezes, envolvendo a memória de outras personagens; procuramos perceber como tal processo se interliga a intenção do romance de buscar inteireza de identidade da personagem. Para tanto, buscamos compreender a postura do narrador contemporâneo e como ele se manifesta na produção de Lisboa, além de apreender também o tratamento de questões acerca de eventos históricos traumáticos, como o regime civil-militar brasileiro em 1964. A intenção é, portanto, entender como o contato que a narradora mantém com esse universo memorialístico, as relações que constrói com outros personagens contribuem para o estado final de inteireza da protagonista e, consequentemente, para a maneira como narra. Como base teórico-crítica recorreu-se a estudos de Karl Eric Schøllhamer (2011), Theodor Adorno (2012), Jöel Candau (2011), entre outros.

Palavras-chave: Adriana Lisboa; narrador contemporâneo; memória; identidade; ditadura civil-militar brasileira.

Abstract: This study aims to understand the narrator in the novel Azul-Corvo (2010). Thus, it is necessary to understand how this narrator, who is Evangelina, behaves in front of her with all the work about collecting and organizing memories, these sometimes involving the memory of other characters; we try to perceive how such a process interconnects the intention of the novel to seek totality of the character's identity. To this end, we seek to understand the posture of the contemporary narrator and how it manifests itself in Lisboa's production, in addition to apprehending the treatment of questions about traumatic historical events, such as the Brazilian civil-military regime in 1964. The intention is, therefore, understand how the narrator's contact with this memorialistic universe, the relationships she builds with other characters contribute to the protagonist's final state of wholeness and, consequently, to the way she narrates. As a theoretical-critical basis, studies by Karl Eric Schøllhamer (2011), Theodor Adorno (2012), Jöel Candau (2011), among others, were used.

Keywords: Adriana Lisboa; Contemporary narrator; Memory; Identity; Brazilian civil-military regime.

1 Mestranda em Estudos literários pelo Programa de Pós-Graduação em Letras e Linguística da Universidade Federal de Goiás (UFG); Bolsista da Coordenação de Aperfeiçoamento de Pessoal de Nível Superior (CAPES). E-mail: thaynacavalcante.m@gmail.com

2 Professora de Letras: Português e Bacharelados e de Estudos Literários do Programa de Pós-Graduação em Letras e Linguística da FL/UFG. E-mail: larissacruvinel@hotmail.com 


\section{CONSIDERAÇÕES INICIAIS}

A literatura contemporânea e o romance contemporâneo, por extensão, não precisam fundamentalmente representar a atualidade, mas se compreender nela, pensando aspectos que estruturam o presente e que, por vezes, se encontram ligados, mesmo que indiretamente, a ele. Como não há ainda um distanciamento temporal, é difícil enxergar o que está tão perto, deixando a percepção crítica às escuras em alguns momentos. Nessa querela, o escritor contemporâneo flerta com a vontade de se envolver com a "realidade histórica", ao mesmo tempo que leva consigo a consciência da incapacidade de perceber completamente a especificidade dessa no presente. Existem algumas incursões da crítica acerca do caráter do romance contemporâneo, haja vista a postura que toma diante do trabalho com o tempo, com a capacidade de captá-lo, enxergá-lo, não necessariamente compreendendo-o ou o representando diretamente. (SCHØLLHAMER, 2011, p. 10).

Tendo em mente tais aspectos é que se faz necessário pensar também na posição do narrador produzido pelo e para o texto literário contemporâneo. Assim, tal qual a literatura contemporânea busca manter essa relação intrínseca de procurar compreender o presente, e se debruçar com certa estranheza e desconforto frente o passado, o narrador também o faz; e essa postura que toma reflete a descentralização do discurso canônico, dando espaço ao trabalho com diferentes discursos advindos de vozes e apreensões da realidade distintas aquelas eurocêntricas, heteronormativas, enclausuradas em "pureza étnica", concentrados em visões excludentes e, por vezes, misóginas. (GINZBURG, 2012, p. 201). Os discursos nos textos literários contemporâneos buscam ser outros, buscam lugar em outros espaços e se fazem e se refazem diante da dimensão e da compreensão do tempo, que redefine e repensa os ideais de linearidade, reexaminando essa narração que tem por base a causa-efeito.

Sobre isso, Regina Dalcastagnè (2012) assevera, no capítulo "O narrador e suas circunstâncias", de seu livro Literatura brasileira contemporânea: um território contestado, que ainda que as narrativas busquem esse distanciamento de uma narrativa tradicional tendência herdada da modernidade - ainda há escritores que se voltam para o trabalho com tempo o cronológico de modo que se compreenda, por exemplo, a partir das apreensões do passado, o presente. Esse posicionamento é necessário para que problematizemos também a nossa própria presença no mundo, afirmando que essa é fruto também do tempo. Assim, a narrativa contemporânea teria como intento conceber e compreender as possíveis maneiras das pessoas "se situarem no mundo, representando a si e aos outros, estabelecendo uma identidade a partir do que tentam fazer, ou daquilo que alcançam dizer". (op. cit., p. 130).

A teoria literária bem nos explica as transformações pelas quais o narrador e sua função passam à medida que se transformam os gêneros literários, as noções de tempo e espaço que se modificam, as compreensões do homem acerca de si e da posição que toma no mundo, das necessidades culturais e das intenções do texto. Assimilando assim, as razões pelas quais esse narrador se transforma, o seu rompimento com os ideais clássicos da epopeia, que deságua na perda da condição totalitária, onisciente e incontestável pela qual era tomado e que, por vezes, conduzia a narração.

O filosofo e ensaísta frankfurtiano Theodor Adorno (2012, p. 56 e 57), em um de seus ensaios "Posição do narrador contemporâneo", que compõe a obra Notas de literatura, ao 
discutir sobre o declínio da narração - aquela vinda da epopeia e que se delineia pela intenção do ato de narrar, ou seja, aquele de transmissão oral, postula que esta, na modernidade, passa a ser mais fugidia, apoiada na organização vinda da consciência. A narrativa linear, intimamente ordenado com o tempo cronológico se modifica, haja a necessidade da linguagem, do discurso, de se desenvolver e se subscrever na própria matéria do romance, gênero representativo da modernidade.

Portanto, tal ideia é refletida na postura ideológica do narrador que pensa e representa o mundo pelo viés do processo de individualização, de subjetividade - o indivíduo que é capaz de aproximar de si mesmo e das coisas que o cercam. Isso posto, o autor questiona o lugar do narrador, sua onipotência, a fala marcada e interpretada como verdade absoluta. Dada a crise da objetividade literária, o narrador, para Adorno, reconhece-se como incapaz de construir a totalidade, inábil para representar fidedignamente a realidade. Isso, parece, se deve também às condições sócio-históricas, às grandes guerras e à dessensibilização quanto aos horrores vividos, fazendo com que a "identidade da experiência, a vida articulada e em si mesma contínua" fosse deixada; "a narrativa que se apresentasse como se o narrador fosse capaz de dominar esse tipo de experiência seria recebida, justamente, com impaciência e ceticismo." (op. cit., p. 56). Não havia mais a mesma adesão às narrativas que contassem de forma simples, direta, como quem conta aventuras.

Deste modo, o narrador deixa na matéria narrada suas impressões, ele se posiciona independente da participação direta, experienciada ou não, das ações que conta. Esse processo atinge também as experiencias do leitor, fazendo com que exista agora, alguma cumplicidade e participação daqueles que empreendem a leitura. (BENJAMIN, 1996, p. 201).

Dalcastagnè afirma que o narrador contemporâneo não é mais aquele detentor da verdade e que ao acompanhar o leitor para dentro da trama, ele empenha - no que considera a pesquisadora - estratégias, esbarra em perspectivas distintas da sua, tem lapsos, coisas que não lembra e não sabe, assumindo seu caráter ficcional. Assim, o leitor suspeita, não mais lê com olhos de confiança, não assume tudo como verdade, haja vista, que o narrador se torna figura suspeita. Dessa forma, os narradores “já nem pretendem mais passar a impressão de que são imparciais; estão envolvidos até a alma com a matéria narrada. E seu objetivo é nos envolver também, fazer com que nos comprometamos com seu ponto de vistas ou, pelo menos, que percebamos que sempre há um ponto de vista com qual se comprometer". (op. cit., 2012, p. 126). É este narrador suspeito que comparece em grande parte da produção literária contemporânea, uma figura que segreda, engana, que desconhece, que inventa e afirma que inventou, que se posiciona a partir de um ponto de vista e convida o leitor a se embrenhar na narrativa com ele.

Assim, à medida que o romance contemporâneo se constrói e se delineia, e em razão do trabalho mais acentuado que realiza com questões que não são canônicas - a diferenciação de apresentação das vozes (marginalizadas, preteridas, normalmente pautadas nas figuras que formulam uma minoria - pobre, negro, mulheres e etc.), na decisão do conteúdo, na maneira como escolhe trabalhar com o material literário, o uso e o emprego da linguagem, fazendo com que a partir disso o narrador assuma olhares mais problematizadores. O narrador não parece mais ter como preocupação primeira uma narração que parta e trate exclusivamente daquilo que é verossímil, no sentido de representar a realidade de modo 
direto. Dessa forma, não existe mais a preocupação e a necessidade de que o narrador participe dos fatos, para aquilo que é narrado ganhe espaço, não há a necessidade da presença, da experiencia pessoal e direta. Assim, nesse contexto, a crítica pensa na possibilidade de uma narração de memória, feita a partir dessa, e que seja, como é entendida aqui, herdeira.

De tal modo, levando em consideração as discussões anteriormente levantadas, é que o presente artigo busca compreender a relação que o romance Azul-Corvo, de Adriana Lisboa, publicado pela primeira vez em 2010, mantém com as apreensões feitas acerca do narrador contemporâneo, haja vista o trabalho com a memória e a posição que a narradora do respectivo romance toma. A narradora deste romance se encontra afastada dos acontecimentos históricos que são retratados no decorrer do enredo, além da condição de fragmentação dela, e que busca dentro da forma como empreende a narração à inteireza, repassando essas questões ao leitor. Assim, é intento deste trabalho discutir e compreender a maneira pela qual essa narradora herdeira de uma memória intergeracional, se posiciona e se completa, a fim de compreender não só a história individual, subjetiva, uma memória-interna (subjetiva, de experiência, específica da narradora-personagem), como uma memória-externa (coletiva/social), no sentido também de compreender a história do Brasil, entender a coletividade que contribui para a formação de identidade dela.

\section{EVANGELINA, A NARRADORA HERDEIRA DE AZUL-CORVO E O TRABALHO COM A MEMÓRIA}

Azul-Corvo (2010) é o quinto romance da escritora carioca Adriana Lisboa, e traz Evangelina como narradora e protagonista. A narração se dá em primeira pessoa e rememora alguns momentos de infância e de adolescência da personagem. É importante ressaltar que a narradora, no momento em que enuncia, já tem vinte e dois anos. A narradora do romance de Lisboa, logo em um dos primeiros capítulos da narrativa, nos explica a sua condição de filha de mãe brasileira e pai norte-americano - esse é figura afastada e de quem, por muito tempo, ela só o nome sabe, Daniel. Ela nasce em Albuquerque, nos Estados Unidos, mas vive pouco tempo lá, vindo para o Brasil com Suzana, a mãe, ainda com dois anos de idade. Aos treze anos da protagonista, sua mãe morre o que impele em Evangelina, a necessidade de buscar conhecer o pai biológico. Para isso, entra em contato com Fernando, homem que foi casado com sua mãe antes de seu nascimento, e que por pedido desta, registrou a protagonista como filha. Fernando é também ex-guerrilheiro, o homem combateu e participou da Guerrilha do Araguaia.

É neste ambiente que a narração ganha corpo, e se encaminha para explicar a jornada que Evangelina empreende na tentativa de se redescobrir, de se complementar e compreender a própria identidade. A morte da mãe é uma cisão entre a inteireza da personagem, para um lugar de fragmentação que gera incômodo e a sensação de não pertencer a nenhum lugar, ou melhor, a um não lugar. (LISBOA, 2010, p.17). No afã de percorrer e refazer os caminhos voltando aos Estados Unidos, com a intenção de procurar no pai respostas, a garota encontra e conquista em Fernando um espaço de compreensão e amparo fraterno. A relação que ambos mantêm é de extrema importância para a construção identitária de Evangelina, que busca no homem e em suas memórias - seja aquelas que se interligam à mãe, e consequen- 
temente a uma história subjetiva, como outras que relembram o passado de Fernando, seu envolvimento em oposição à ditatura e a guerrilha, memórias essas que ilustram a História do país, e que mesmo temporalmente distante de Evangelina, dizem respeito a ela também.

A memória de Fernando sobre o Brasil, sobre o contex to do regime ditatorial civil-militar em 1964, seu treinamento de táticas de guerrilha e o tempo que passou na China, sua contribuição para a organização das ações da Guerrilha do Araguaia, seus ideais políticos, o amor que viveu, a tensão do período, os horrores que ele presenciou, os combates ideológicos, as mortes, os sumiços, as torturas, tudo contribui para a organização e o regaste de memória de Evangelina. Ainda que ela diretamente não tenha vivenciado esse período e que para a menina, todo esse contexto se firmasse como coisa distante, que teve contato através da escola e que mesmo lá, "durante as aulas de história do Brasil, tudo era maçante, distante e levemente inverossímil” (LISBOA, 2010, p. 44) e que fazia, na verdade, era acompanhar pombos do lado de fora da sala, e afirma que quando pensava em anos sessenta pouco lhe diziam sobre ditatura e sim sobre uma série de televisão norte-americana que levava sessenta no nome. Essa passagem presente no romance evidencia o distanciamento que a garota tinha acerca dessa questão, que passa a ser fato de extrema necessidade quando ela procura em Fernando compreender a si. Esse processo de construção de identidade através da memória - e aqui se verte em destaque a condição de uma memória externa, um tanto mais ampla, que contextualiza um período da história nacional, uma memória que mesmo vinda de Fernando é coletiva, que faz parte do "ser brasileiro" e da identidade do povo.

Em mesma intensidade, a figura de Fernando também contribui para a junção das memórias e o esclarecimento que Evangelina busca, acerca de seu nascimento, das decisões da mãe de: voltar ao Brasil, não incluir o pai biológico em sua criação, de casar e separar do brasileiro, de pedir que esse mesmo homem registrasse a filha, além de buscar refazer e reconstruir as ligações afetivas da mãe nos Estados Unidos na tentativa de encontrar o pai. Evangelina, no inicio da narração e no decorrer dela, parece ter total convicção de que na figura paterna biológica reaveria o lugar que lhe faltava, que recuperaria aquela sensação de pertencer enquanto Suzana estava viva.

Isto posto, é que pensamos nesta análise a maneira pela qual a memória intergeracional contribui para a construção da narração. Evangelina enquanto narra é fruto disso, os feitos de Fernando, as memórias construídas sobre a mãe, as coisas que aprende sobre seu nascimento, sobre os dois anos infante que viveu em Albuquerque, a memória coletiva a respeito do contexto ditatorial civil-militar, todas essas coisas são levantadas através do trabalho e da angariação de memórias. É assim uma herdeira, como postulado nesta pesquisa, das memórias de Fernando e de outras personagens e das memórias nacionais; constrói a si e ao enredo a partir dessa junção, da associação desses relatos perpassados a ela.

Assim, Maurice Halbwachs (1990), explica a existência de duas memórias, uma que classifica como interna e outra como exterior. O indivíduo que usa dos artifícios do relembrar, não o faz apenas projetando e interpelando suas próprias memórias, precisa também se formar a partir das memórias que vêm de terceiros. Evangelina persegue seu passado também através das memórias de outras personagens com quem mantém contato durante a narrativa, principalmente Fernando; com o intuito de compor as lacunas, une às suas memórias individuais as memórias coletivas. Ela se alia a um passado que não é seu, lem- 
branças também que não são suas, coisas que não viveu, compondo um presente, assim, que é feito por ela. Esse movimento que permite relação e que contribui com a sua própria jornada de descobertas, consequentemente, compõe também sua identidade. Deste modo, Halbwachs diz que:

Seria o caso, então, de distinguir duas memórias, que chamaríamos, se o quisermos, a uma interior ou interna, a outra exterior; ou então a uma memória pessoal, a outra memória social. Diríamos mais exatamente ainda: memória autobiográfica e memória histórica. A primeira se apoiaria na segunda, pois toda história de nossa vida faz parte da história em geral. Mas a segunda seria, naturalmente, bem mais ampla do que a primeira. Por outra parte, ela não nos representaria o passado senão sob uma forma resumida e esquemática, enquanto que a memória de nossa vida nos apresentaria um quadro bem mais contínuo e mais denso. (ibidem, p. 37).

A narradora de Azul-Corvo busca organizar e contar essas memórias a fim de elucidar o processo de reconstrução da fragmentação em que se encontrava Evangelina após a morte materna. Tanto o é, que a narração em presente se dá através da figura, já em sua inteireza, de Evangelina, a mulher de 22 anos que narra, reflete sobre si, a jornada e tudo o mais que viveu nesse determinado período. É já na certeza da chegada, do encontro do próprio espaço, da própria identidade que a narradora fala.

Sobre tais ocorrências em relação a constituição e a recuperação da memória, e uma memória geracional, em Azul-Corvo, pode-se empreender respaldo na pesquisa de Jöel Candau, em Memória e identidade (2014, p.139), considera sobre a reapropriação da identidade como processo que perpassa pela aproximação do indivíduo junto à memória genealógica, que precisa necessariamente ser transmitida, uma vez que em contato com a memória dos ancestrais é um caminho direto para contribuir com a preservação da própria identidade. Todavia, é importante salientar que no caso do romance em questão é preciso se ater à memória geracional, que ao contrário da memória genealógica - que está interligada à busca de compreensão da trajetória dos pais ou avós com intuito de autoconhecimento, e que precisa abranger duas ou três gerações - aquela primeira se estende, tocando muitas outras gerações. Assim, podendo haver dois distintos modos de se dar - antiga e moderna, aos fins desta pesquisa e pensando naquilo que é feito no texto de Lisboa é de nosso interesse pensar na forma antiga, já que essa é "a consciência de pertencer a uma cadeia de gerações sucessivas da qual o grupo ou o indivíduo se sente mais ou menos herdeiro”. (op. cit., 2014, p. 142).

A memória parece atuar em Azul-corvo de forma a elencar ponto a ponto da narrativa, conectando assim passado e presente(s), sendo que, por vezes, o passado não pertence às memorias da narradora. Evangelina vai articulando, assim, memórias exteriores a si, se apropriando delas e construindo a sua própria história. A memória individual é construída também pelo viés da coletividade; é o se pôr em condição de alteridade, e sendo a família um dos núcleos sociais de maior contato e, por vezes, maior proximidade é a partir dela que essa relação se põe. Evangelina assim o faz, mesmo sem relação consanguínea com Fernando, faz dele, através do contato, da intimidade da vida doméstica e do cotidiano, sua família. 
Ao aprender sobre o passado do ex-gerrilheiro, do ex-marido de sua mãe, esses passados a compõe. As histórias de Fernando, em certa medida, são delas também. Sobre isso, Jöel Candau (2011) assevera que:

A memória familiar serve de princípio organizador da identidade do sujeito em diferentes modalidades. De um lado, intervém o compartilhamento de certas lembranças e esquecimentos (em particular o dos mortos) ou, mais exatamente me parece, o compartilhamento da vontade de compartilhar [...] à qual cada indivíduo se lança ao mobilizar as funções de revivescência e reflexividade. Essa reapropriação é sempre específica e o sentido que ela confere aos acontecimentos familiares memorizados é irredutivelmente singular, idiossincrático. [...] essa reapropriação permite ao indivíduo elaborar e logo narrar sua própria história, que será confrontada com a de outros membros da família. [...] Ao mesmo tempo que constrói sua identidade pessoal por uma totalização provisória de seu passado, o indivíduo realiza, portanto, a aprendizagem da alteridade. Desse ponto de vista, a memória familiar é para o indivíduo ao mesmo tempo a consciência de uma ligação e a consciência de uma separação. (ibidem, p. 140 e 141).

Desse modo, Halbwachs (1990, p. 37 e 38) aponta que inseridos em sociedade, independente do tamanho que tenha - grande ou pequena, teríamos uma construção de memórias que se intercala e se transpõe individuais e coletivas, assim, um mesmo indivíduo partilharia de ambas. Todavia, faz uma ressalva, dizendo que apesar de encontramos na memória coletiva apoio para a compreensão e construção daquelas que nos são próprias, não significa que elas deixem de ser subjetivas, menos fruto de subjetividade por essa razão. A correlação das memórias se dá de maneira tão intrínseca, em essência se tornam interligadas, que aquilo que é coletivo se torna parte também do individual. A questão que se põe é o fato de que a memória coletiva por mais interligada que esteja à individual, assimila as lembranças subjetivas em uma outra ordem; quando se evoca as memórias coletivas existe a necessidade de se acreditar naquilo que vem de conhecimentos externos, que vem do outro, lembranças que não foram diretamente experenciadas que foram adquiridas e assimiladas no imaginário. Portanto,

consideremos agora a memória individual. Ela não está inteiramente isolada e fechada. Um homem, para evocar seu próprio passado, tem freqüentemente necessidade de fazer apelo às lembranças dos outros. Ele se reporta a pontos de referência que existem fora dele, e que são fixados pela sociedade. Mais ainda, o funcionamento da memória individual não é possível sem esses instrumentos que são as palavras e as idéias, que o indivíduo não inventou e que emprestou de seu meio. (op. cit., p. 38).

Isso é claramente observado no romance de Lisboa, quando pensamos na situação em que se encontra Evangelina na infância em contraposição ao modo maduro e assertivo que a narradora, já na vida adulta, se posiciona ao narrar. O leitor, em razão disso, recebe mui- 
tas informações que foram complementadas com um olhar distinto, com informações que vieram de pesquisa, afirmações que são frutos de observação posterior. Nas informações passadas por Fernando, a narradora nos conta, existia espaços não preenchidos, vácuos, informações não conectadas, e no processo e apreensão e compreensão que faz das informações vindas dele, a narradora completa, seja com memórias próprias, seja com pesquisas, seja também com invenção.

Exemplo possível disso vem do trecho em que Evangelina narra a história de uma das primeiras relações amorosas e sexuais de Fernando, a fim de completar a ideia que destaca, de que Chico (codinome pelo qual era reconhecido dentro da organização de oposição ao regime estatal ditatorial) era bom com armas e mulheres. Assim, a narradora nos explica que o ex-guerrilheiro a havia confidenciado uma paixão de adolescência que fora, por ele, pedida em casamento. Complementando tais fatos, Evangelina caracteriza tanto a mulher como a relação que mantiveram, dizendo-a uma prostituta que teve na verdade, alguns sentimentos de pena em relação a inocência do adolescente Fernando. A narradora afirma, portanto, que nem tudo nessa história se pós da maneira como ela conta e que foi nos espaços de silêncio que ela concebeu o que repassa ao leitor:

Ele não me disse prostituta. Definiu-a certo dia, depois de ter tomada umas cervejas, como uma moça que trabalhava numa dessas casas de moças, e a minha imaginação foi completando o resto, foi pescando os significados do silêncio dele, pendurados no ar como esses balões das histórias em quadrinhos. Ele disse que gostou dela, e eu pensei no decote da blusa e achei que podia de fato ter sido assim, da mesma maneira como pensei algumas outras coisas ao longo desses anos. Afinal, se as pessoas não me forneciam detalhes, eu tinha o direito moral de providenciá-los eu mesma. (LISBOA, 2010, p. 44 e 45, últimos grifos nossos.)

É assim que se torna possível também perceber uma outra tendência presente na postura da narradora do romance Azul-Corvo. Em medida que caminha nesse processo de aquisição e resgate direto nas memórias que lhe são contadas, seja por Fernando ou pelos demais personagens, referências documentais fruto de pesquisa são também usadas para compor o texto. Essa estratégia extrapola apenas a noção conteudística do texto, sendo também parte do projeto estrutural dele. São retirados e empregados a narração, em um processo de trabalho intertextual e metaficiconal, comentários da internet, referências retiradas de sites de busca e de parecer de organização histórica - enciclopédico, verbetes entre outros. São múltiplas as ocorrências disto no decorrer do romance, aparecem trechos da resolução do partido político PC do B, a repetição de slogans do governo militar, a transcrição da placa inaugural da transamazônica, documentos vindos do governo que explicavam, ao seu modo, a situação da Guerrilha do Araguaia, documentos e registros das capturas e mortes, manifestos dos partidos de oposição, entre outros. Como por exemplo:

Também em maio a guerrilha assinou seu primeiro comunicado. Não mencionava o Partido nem falava do treinamento que vinha acontecendo na mata havia alguns anos. Mas anunciava a criação da União pela Liberdade e pelos Direitos 
do Povo, a ULDP.

O povo unido e armado derrotará seus inimigos.

Abaixo a grilagem!

Viva a liberdade!

Morra a ditadura militar!

Por um Brasil livre e independente!

Em algum lugar da Amazônia, 25 de maio de 1972.

Comando das Forças Guerrilheiras do Araguaia. (LISBOA, 2010, p. 118 e 119).

Observemos assim a relação que mantém com o texto original:

O Movimento de Libertação do Povo (MLP) e as forças guerrilheiras do ARAGUAIA apelam para os moradores da região a fim de que engrossem a resistência à odiosa ditadura militar, aos grandes magnatas, aos grileiros e aos gringos norte-americanos que, no norte e nordeste do País, já se apoderaram de imensas extensões de terra e das ricas minas de ferro da Serra Norte perto de MARABÁ. A todos conclamam a se estruturar nos comitês do MLP ou em outras formas de organização. Não há outro caminho para o povo senão o de combater valentemente os opressores. Cada lavrador, cada posseiro, cada trabalhador de fazenda ou castanhal, cada injustiçado, cada patriota, deve ajudar, de todos os modos, os que enfrentam sem temor as tropas do governo de traição nacional.

O povo unido e armado derrotará seus inimigos.

Abaixo a grilagem!

Viva a liberdade!

Morra a ditadura militar!

Por um Brasil livre e independente!

- Em algum lugar da Amazônia, 25 de maio de 1972

O MOVIMENTO DE LIBERTAÇÃO DO POVO (MLP) 
O COMANDO DAS FORÇAS GUERRILHEIRAS DO ARAGUAIA. (Comunicado no. 1 do Movimento de Libertação do Povo (MLP) - Forças Guerrilheiras do Araguaia, 1972). ${ }^{3}$

Esse emprego não nos parece desmedido e ajuda a construir uma ideia da relação que a memória externa mantém com os fatos narrados por Evangelina. Como que aquilo que não era dela, passa a ser e juntos, convergem para uma ideia de memória que desagua em intenção de narrar. O romance não conta sobre o período ditatorial, mas faz dele abrigo para complementar a história de Evangelina. Tudo que vem da história nacional, tudo que é fato e contribui para os acontecimentos que levaram Fernando até os Estados Unidos também é dela, e necessários para a compreensão da sua história. A identidade nacional que vai se formando conversa, e com muita intimidade, com a intenção da garota de buscar saber sobre si, suas raízes, quem é seu pai e o que tem dele, saber sobre a mãe e como ela viveu; todas essas lembranças, todas as histórias que antecedem a sua própria são importantes para a compreensão de quem Evangelina é.

\section{RELAÇÃO FERNANDO-EVANGELINA: A LIGAÇÃO QUE PERMITE A TRANSMISSÃO INTERGERACIONAL DA MEMÓRIA A FIM DE COMPLETAR IDEAIS DE IDENTIDADE}

Durante toda a narrativa o leitor recebe esmiuçado diante dos seus olhos o desenvolvimento da relação de Fernando e Evangelina. Percebemos a confiança que vai se criando, a afinidade doméstica e cotidiana que vai permitindo a abertura de ambos para confiar segredos, para se abrirem sobre Suzana, para que Fernando conte e deposite em Evangelina toda a carga emotiva do seu passado, em especial as vivências como guerrilheiro e a decisão de deixar, sem retorno, o Brasil.

Esse processo de construção da intimidade e da relação fraternal de ambos é de grande importância para a compreensão da transmissão intergeracional das memórias que vão compor a narrativa, além de contribuir também para o processo de reconstrução da personagem Evangelina que se faz necessário para a condição em que se põe a narradora, já aos vinte e dois anos. A narração em Azul-Corvo (2010) se preocupa em fazer esse bordado de memórias - aquelas individuais, próprias da menina, as que vêm de outras personagens, principalmente Fernando, as memórias de apreensão nacional, aquelas retiradas de livros, textos, documentos, além de complementar tudo que for vazio, tudo que falta com invenção, com imaginação. Assim, se torna possível perceber e pensar acerca da inclinação do romance de buscar formação, de mostrar o processo de reconstrução da identidade de Evangelina.

A memória se faz presente em todo o romance, e é estratégia para fins de narração. Assim, no afã de se formar, de redescobrir raízes, de conciliar em si a parte que falta, Evangelina encontra na memória esse espaço, o que resulta nessa narradora já distanciada dos

3 Trecho do primeiro comunicado do Movimento de Libertação do povo. Cópia da Documentação apreendida pela repressão no aparelho do PC do B na rua Pio XI, São Paulo em dezembro de 1976. Vinda da Geração Editorial. Transcrição e HTML feitos por Fernando A. S. Araújo, em maio 2006. Disponível em: https://www.marxists.org/portugues/tematica/1972/05/25.htm. 
eventos, não mais fragmentada, e que em um processo inter e extra-estético, organiza todos esses fatos, todos esses saberes memoriais para nos contar a sua história. Desse modo, a narração e a narradora do romance de Lisboa, através do movimento de recuperação e trabalho da memória intergeracional, estão carregadas da tentativa de representar a busca formadora e integradora, fixante de identidade dessa personagem fragmentada e fragilizada após a morte da mãe.

É assim, que esta análise pensa no passado da guerrilha de Fernando, e como através dele, Angelina conhece também o homem que lá habita. Descobre o porquê do distanciamento de Fernando das pessoas, seus silêncios, entende a culpa que ele sente por ter sobrevivido, além de tomar para si a responsabilidade de relembrar e de contar a história dele. Nos parece facilmente identificável e de extrema capacidade elucidativa, através do trabalho com a memória ditatorial, entender como a narradora busca nessas relações compreender não só a trajetória externa a ela - a memória de nação e a de Fernando, como a sua própria. Como já, amplamente discutido aqui, a memória é um elemento essencial para construir identidade, e essa necessidade é primeira nos indivíduos. Assim, a pesquisadora Beatriz Sarlo (2007), em seu livro Cultura da memória e guinada subjetiva, ao discutir a transmissão e o trabalho com aquilo que está no passado, assevera que:

É possível não falar do passado. Uma família, um Estado, um governo, podem sustentar a proibição; mas só de modo aproximativo ou figurado ele é eliminado, a não ser que se eliminem todos os sujeitos que o carregam [...]. Em condições subjetivas e políticas "normais", o passado sempre chega ao presente. (op. cit., p. 10).

Desse modo, as cenas proeminentes da ditadura ajudam a elucidar a relação que Fernando e Evangelina mantêm, já que, é na menina que o homem decide se abrir, contar sua história, depositar em Evangelina suas memórias. Acontecimentos traumáticos que o impedem de dizer; são memórias com as quais ele pouco trabalhou, pouco dividiu. Mesmo com a mãe de Evangelina, não houve tanto compartilhamento, sendo ela, segundo descrições da narradora, mulher que o arrebatou desde o princípio - "Ele a viu e decretou a continuidade do mundo, a extensão do tempo. [...] Ele a viu e pensou que precisava, com desespero, de algo em que pensar." (LISBOA, 2010, p. 130).

Assim, a narradora nos explica, que aos poucos ela vai tocando em assuntos do passado, sentindo a necessidade e a liberdade que o ex-guerrilheiro vai lhe dando, é a caixa de vinho com documentos sem ordem, são as perguntas que ora ele deixa entrever alguma resposta, até que, em meio a viagem que fazem para conhecer uma amiga da mãe que vai ajudá-los a entrar em contato com a família do pai, Daniel, que Fernando decide contar toda a história à Evangelina. Fato esse que a narradora toma como uma espécie de "indenização da mãe", das coisas que ele não contou à mulher, mas que pôde depositar na filha dela.

À medida que a construção da relação das duas personagens se afunila, podemos ver o quão complexa vai se tornando. Eles já têm na figura um do outro, espaço de confiança, de carinho, por vezes, de necessidade; Fernando parece encontrar em Evangelina uma necessidade que não sabia que tinha, ele deposita na menina, como já explicitado aqui, as mágoas, os medos, os silêncios que guardou durante anos. Existe nele a culpa do sobrevivente, 
o que, aos fins de narração, impossibilita que ele mesmo conte sua história. O sobrevivente, assim, experiencia o "sentimento paradoxal da culpa da sobrevivência." (SELIGMANN-SILVA, 2008, p. 75). Fernando por si, não conta, porque sente culpa por viver, por ter desertado, sente as dores que lhe foram ausentes.

As coisas estavam alagadas por um deserto branco que vinha de dentro e se alastrava, um deserto viral, contagioso, onde os sons era difusos, os sabores eram rasos, a visão imediatista.

E a vida era uma contradição de termos: ele havia deixado a vida para trás a fim de continuar vivo, anos antes, e essa equação funcional e ilógica dava choques elétricos todos os dias nas cicatrizes abertas que ele não guardava do suicídio que não havia tentado cometer. (LISBOA, 2010, p. 130 e 131).

Evangelina se torna assim, a responsável por contar a história de Fernando, ao que intercala a história dele à sua própria. Ela é herdeira dessas memórias, desse passado, nela existe a confiança para compartilhar, o espaço para dividir a dureza da vida guerrilheira, as experiências que Fernando teve enquanto Chico, como também a paixão que sentiu por Suzana, o respeito por ela, a promessa de estar e de se fazer presente, o pedido que, partindo dessa certeza de alguma permanência, faz com que ele registre o bebê da ex-esposa. A narradora, no presente da narração, é o resultado disso, é o resultado da construção, organização e reflexão acerca das memórias internas e externas, é uma narradora pronta, reintegrada a si mesma, é o resultado do fim da jornada empreendida no começo.

Sobre tais prerrogativas presentes em Azul-Corvo - a da transmissão da memória, e uma memória que se vincula intrinsicamente com o trauma advindo de um período histórico completamente conturbado e marcado por violência, e da situação de Evangelina como a receptora do discurso traumático de Fernando e por conseguinte, a transmissora, a narradora desses, é que se pode correlacionar ao que escreve a professora e filosofa Jeanne Marie Gagnebin, em seu Lembrar, escrever, esquecer (2006), quando pondera sobre a natureza do conceito de testemunha; a pesquisadora afirma assim, que a ideia de testemunha para o narrar de histórias não ficaria encarcerada em uma visão semântica da palavra, não seria uma testemunha direta, mas que se estenderia aqueles que a ouvem e permanecem, é o "que consegue ouvir a narração insuportável do outro e que aceita que suas palavras levem adiante, como num revezamento, a história do outro: não por culpabilidade ou por compaixão, mas porque somente a transmissão simbólica" (op. cit., p. 57) pode inventar o presente, não permitindo a repetição do passado. Assim, Evangelina o faz, ela recebe a dureza da história de Fernando, ouvindo-a e depois, em um processo de absorção dessas memórias, completa as sus próprias, o que contribui para sua busca por identidade.

O laço fraternal que se constrói e se estabelece entre Fernando e Evangelina é um espaço de liberdade, de confiança. Existe a permissão da escolha, eles se escolheram - "Você é o que meu? Perguntei ao Fernando. [...] Não sei. O que você quiser que eu seja, ele respondeu." (LISBOA, 2010, p.148). E é nessa atmosfera de compatibilidade, confiança que Evangelina vai aos poucos se encontrando, descobrindo quem é, porquê o é, vai descobrindo a mãe, vai 
descobrindo em Fernando o pai que viajou para encontrar, vai percebendo que tudo que fez, aprendeu a mudou, que aos poucos deixa de ser uma estranha, tanto a nível físico, quanto à nível psicológico e emocional. É importante lembrar que a inteireza da identidade da menina, vai se construindo aos poucos e que outras razões além do trabalho de angariação, organização e reflexão acerca das memórias - internas e externas - como por exemplo, o contato que vai tecendo entre si e o lugar, a compreensão de pertencimento de duas nações.

Todavia, percebemos que através da transmissão intergeracional, do contato com as memórias de Fernando, especialmente aquelas que, apesar de serem dele, contribuem para o reconhecimento da história nacional, do contato perdido com uma parte fundamental da história brasileira, contribuem para a sua integração, para seu estado de inteireza. De algum modo, ao compreender Fernando, compreende a mãe e por fim, compreende a si mesma dentro dessa relação interdependente. A narradora como produto dessa trajetória, e, já consciente de toda a sua condição de inteireza, dona de alguma certeza sobre a sua identidade, respalda a compreensão do trabalho com a memória como necessário para a construção do romance.

\section{CONSIDERAÇÕES FINAIS}

Empenhada a presente análise, procuramos compreender como a narradora de $\mathrm{Azul}$ -Corvo se constrói e se comporta a partir da percepção, da construção e organização da memória. Além de compreender também como as relações que construiu durante a jornada, pela qual o romance se fia, em principal com a figura de Fernando, ajudam na busca acerca da identidade de Evangelina - percebendo, assim, que através da apreensão das memórias, ela pôde através de uma ligação intergeracional criar um estado de inteireza. O trabalho que empreende correlacionando suas memórias à de terceiros, nos parece ser necessária para a posição que a narradora toma para si, ao narrar, e de modo reflexivo, aos vinte e dois anos. É uma Evangelina madura e inteira que se posiciona e conta a história da sua jornada aos Estados Unidos, aos treze anos e pós morte de sua mãe.

Dada essa intenção, percebemos como as memórias internas e externas são de extrema importância para a compreensão, a partir do viés aqui proposto, de que a narradora de Lisboa se forme a partir do trabalho memorial. Ao entender a acuidade das memórias internas como aquelas particulares à Evangelina - as memórias da relação com a mãe, aquelas que a ligavam como parte do Brasil, aquelas que constrói com Fernando e as demais personagens que se apresentam, e as externas como fruto das vivências de terceiros, e aqui em evidência, o ex-guerrilheiro, além da construção da memória nacional. Memórias que não são diretamente suas, mas que contribuem, e enormemente, para quem é e para a história que conta. Cada coisa vivida, externa e internamente, parecem figurar necessidade para a resolução identitária de Evangelina; quem ela é, e onde chegou quando se posiciona no presente da narração é resultado de todas peripécias do caminho.

Entendendo assim, a narradora como fruto dessa memória intergeracional, e postulando a importância dessas mesmas memórias para a maneira como ela se porta, foi preciso compreender, pensar a necessidade das relações afetivas estabelecidas por Evangelina, com 
enfoque em Fernando e no compartilhamento testemunhal das experiências dele sobre os anos de ditadura. Essa memória que parte do homem, extrapola esse nível subjetivo, permitindo também uma noção de pertencimento histórico nacional. As vivências de nação também formam a garota, na mesma intensidade que as memórias voltadas para a própria realidade familiar o fazem também. Não é menos importante a memórias nacionais em relação às memorias sobre a relação do ex-guerrilheiro com sua mãe, Suzana; ambas contribuem para a noção de inteireza que a protagonista procura e narra durante o romance.

Por fim, entendendo a acuidade do romance contemporâneo em relação a postura do narrador desse, e toda a questão que norteia a perda da experiência direta, é que ao fim desta pesquisa, tomamos e compreendemos a narradora Evangelina, aos vinte e dois anos, como figura completa, firmada em um processo de autodescobrimento e firmação de identidade que adveio da exposição às memórias, às trajetórias feitas por ela, com ela e além dela. É, portanto, um narrador feito de memórias, que narra a partir delas. 


\section{REFERÊNCIAS}

ADORNO, Theodor. Posição do narrador no romance contemporâneo. In: Notas de literatura I. trad. ALMEIDA, Jorge de. 2a ed. São Paulo: Duas cidades - Editora 34, 2012.

BENJAMIN, Walter. O Narrador: considerações sobre a obra de Nikolai Leskov. In: Magia e Técnica, Arte e Política: ensaios sobre literatura e história da cultura. São Paulo: Brasiliense, 1996.

CANDAU, Joël. Memória e identidade. São Paulo: Contexto, 2011.

COMISSÃO NACIONAL DA VERDADE. Disponível em: < http://www.cnv.gov.br/>. Acesso: 15 de nov. de 2019.

DALCASTAGNÈ, Regina. Literatura brasileira contemporânea: um território contestado. Rio de Janeiro: Horizonte, 2012.

GAGNEBIN, Jeanne Marie. Memória, história, testemunho. In: Lembrar, escrever, esquecer. São Paulo: Editora 34, 2006.

GINZBURG, Jaime. O narrador na literatura brasileira contemporânea. Tintas. Quaderni di letterature iberiche e iberoamericane. USP. São Paulo: nº 2, p. 199-221, 2012.

HALBWACHS, Maurice. A memória coletiva. São Paulo: Centauro, 1990.

HALBWACHS, Maurice. A memória coletiva. trad. SCHAFFTER, Laurent Léon. $2^{a}$ ed. São Paulo: Vértice, 1990.

LISBOA, Adriana. Azul-Corvo. Rio de Janeiro: Rocco, 2010.

SARLO, Beatriz. Cultura da memória e guinada subjetiva. trad. D’AGUIAR, Rosa Freire. São Paulo: Companhia das letras, 2007.

SCHØLLHAMER, Karl Eric. Ficção brasileira contemporânea. Rio de Janeiro: Civilização Brasileira, 2011.

SELIGMANN-SILVA, Márcio. Narrar o trauma - a questão dos testemunhos de catástrofes históricas. Psic. Clin., Rio de Janeiro, vol.15, nº.2, 2003. 
